\title{
HOW THE CHOICE OF ACADEMIC MAJORS AND STUDENTS' FUTURE ACHIEVEMENTS ACCORDING TO THE TALENT PATH
}

\author{
Zulkifli Amin ${ }^{1}$, Burhanuddin ${ }^{2}$ Teuku Fajar Shadiq ${ }^{3}$ Anwar Soleh Purba ${ }^{4}$ \\ ${ }^{1,2}$ Universitas Muhammadiyah Sumatera Utara, Indonesia \\ ${ }^{3}$ Universitas Islam Syekh Yusuf Tangerang Indonesia \\ 4, Universitas Islam Sumatera Utara, Indonesia \\ Email: zulkifliamin@umsu.ac.id'burhanuddin@umsu.ac.id’teuku_fajarshadiq@unis.ac.id \\ Anwarsolehpurba12@gmail.com
}

Accepted: 03-11-2021

\begin{abstract}
This article described college majors' choices on future learning achievement according to students' talents. The researcher believes that selecting majors according to talent will determine students' success in the future. So, to prove this assumption, we proved it through a study of several related kinds of literature from several educational and higher education journal publications. The publications in question are, for example, ERIC, Google Book, Elsevier, Sagepub, and Taylor and France, which were published ten years ago. We designed this qualitative study with a phenomenological approach. We explored as much data as possible that addresses student choice significant variables and academic achievement when students enter the study period. The analysis model that we did is through data coding, evaluation, and in-depth interpretation to conclude to answer questions on the principle of validity. Based on the findings and discussion data, we could conclude that there is an influence between the choice of majors and college achievement because achievement will be obtained if the field of study follows students' interests and talents. Without interest and talent, it is challenging to achieve porosity following expectations.
\end{abstract}

Keywords: Choice of majors, talents, interests, achievements, and qualitative studies

\begin{abstract}
Abstrak
Artikel ini memaparkan pilihan jurusan perguruan tinggi terhadap prestasi belajar di masa depan sesuai dengan bakat mahasiswa. Peneliti percaya bahwa memilih jurusan sesuai bakat akan menentukan keberbasilan siswa di masa depan. Maka, untuk membuktikan asumsi tersebut, kami membuktikannya melalui kajian beberapa literatur terkait dari beberapa publikasi jurnal pendidikan dan perguruan tinggi. Publikasi yang dimaksud adalah, misalnya, ERIC, Google Book, Elsevier, Sagepub, dan Taylor and France, yang diterbitkan sepulub tahun lalu. Kami merancang penelitian kualitatif ini dengan pendekatan fenomenologis. Kami menggali sebanyak mungkin data yang membahas variabel signifikan pilihan siswa dan prestasi akademik. ketika siswa memasuki masa studi. Model analisis yang kami lakukan adalah melalui pengkodean data, evaluasi, dan interpretasi mendalam untuk menyimpulkan untuk menjawab pertanyaan tentang prinsip validitas. Berdasarkan data temuan dan pembahasan, dapat disimpulkan bahwa ada pengaruh antara pilihan jurusan dan prestasi kuliah karena prestasi akan diperoleh jika bidang studi sesuai dengan minat dan bakat mahasiswa. Tanpa minat dan bakat, sulit untuk mencapai porositas mengikuti harapan.
\end{abstract}

Kata kunci; Piliban jurusan, bakat, minat, prestasi, dan studi kualitatif 


\section{INTRODUCTION}

Learning achievement is the level of achievement of teaching outcomes where a student who has started to develop learning around the field and is ready for the steps of a job call when students enter the world of occupation in the future. ${ }^{1}$ Interest in learning is significant in providing experience, expanding information and abilities. In addition, when they arrive at the level of choosing the right college major, it will be easy to equip students with arrangements and governance even though the era of globalization continues to advance. The problem is how students can become great people to get a lot of high-achieving learning outcomes? Being an extraordinary student at a college is undoubtedly a positive and fun thing for the students themselves, the campus, and even the parents of students.

To be realized, students need certainty and hard work and never give up. Student achievement is not only seen from the quality of scientific achievement and skills. However, also with how students become innovative students-following various campus development activities and scientific and national organizations, how to become future leaders, organization, professionalism, and commitment to education, social and environment wherever they live and in society so that the existence of students with their achievements is practical for many people. ${ }^{2}$

We have to admit that every step and achievement achieved will not come just like that or 'free' in the life of the world of academic education. Everything requires effort and a strong will not play games in achieving what is desired and the obligation to be taken by students Zarina Akhtar. ${ }^{3}$ This is equivalent to trying to be an outstanding student in a university environment. So, a person needs high will and effort, and remember to balance it with prayer and high motivation. ${ }^{4}$ In order to help students work with reasonable strategies to make significant progress, they need support and advice on how to become outstanding students who can go through serious study for the sake of achievement with their talents. Added to this by supporting a very fertile learning climate in universities, student achievement will be easily achieved even though the competition is getting more prominent in competition and learning independence. ${ }^{5}$

1 Sidik Apriansyah, "Hubungan antara prestasi belajar dengan perencanaan karir," PSIKOPEDAGOGIA Jurnal Bimbingan dan Konseling 3, no. 2 (2014): 78-85. Amat Suroso dkk., "Challenges and Opportunities towards an Islamic Cultured Generation: Socio-Cultural Analysis," Linguistics and Culture Review 5, no. 1 (28 Juni 2021): 180-94, https://doi.org/10.37028/lingcure.v5n1.1203.

2 Quoc Trung Pham dan Thanh Phong Tran, "Impact factors on using of e-learning system and learning achievement of students at several universities in Vietnam," dalam International Conference on Computational Science and Its Applications (Springer, 2018), 394-409.

3 Zarina Akhtar, "A Comparative Study of Students Learning Style, Socio-economic Status and Learning Achievement of Developed and Under-developed Districts of Pakistan.," Language in India 11, no. 6 (2011).

4 Rahele Sarikhani, Mostafa Salari, dan Vahid Mansouri, "THE IMPACT OF E-LEARNING ON UNIVERSITY STUDENTS'ACADEMIC ACHIEVEMENT AND CREATIVITY,” Journal of Technical Education and Training 8, no. 1 (2016).

5 Azizah Saad ALRowais, "The impact of flipped learning on achievement and attitudes in higher education," International Journal for Cross-Disciplinary Subjects in Education 4, no. 1 (2014): 1914-21. Prasetyono Hendriarto dkk., "Understanding the Implications of Research Skills Development Framework for Indonesian Academic Outcomes Improvement," Jurnal Iqra': Kajian Ilmu Pendidikan 6, no. 2 (15 Juli 2021): 51-60, https://doi.org/10.25217/ji.v6i2.1405. 
It is not enough to pay attention to activities in class. Students must fully understand the information provided by the instructor Kimberly E. Arnold dan Matthew D ${ }^{6}$. They can also check lesson samples and other information repeatedly by taking individual notes for each lesson. This will help students stay focused and absorb the latest information and updates in their field. Students will also need support from academics and parents to adjust when they return home. ${ }^{7}$ That way, the setup of students will be more experienced because they will be able to practice critical thinking skills and be wise and rational while focusing freely without coercion. If they practice this every day, it is believed that they will get used to it and find it easier to overcome any difficulties they may encounter in class or on exams! Besides that, the university's task is to produce students with high academic achievement scores, but they must become intellectuals who are easily adaptable to modern times and reforms in society and even the global world. ${ }^{8}$.

It is also essential to talk to instructors or educators to help students stay in their studies even after graduation. The teacher must be experienced in the subject matter under consideration. So, the next time a student has a question or concern about his or her field of study, do not hesitate to ask! They can usually help students who can complete assignments or exams without difficulty if they understand the material in the study. ${ }^{9}$ Great conversations with teachers also allow students to associate or experience new things. Who knew he had such a fantastic career that it was so amazing to contribute to the experience? Employers today are looking for competitors who can manage their work and are also willing to conform to the organizational culture and interact with other representatives. Students must acquire nuanced talents as learners. ${ }^{10}$ Since most jobs require collaboration, students must demonstrate a wide range of planning, executing, and achieving goals. To help future student vocations, try to unroll in courses or preparations that they enjoy. Lecturers and teachers can help students by increasing efficiency and building effective connections. Develop an extensive network and prospects. It is common for universities in developed countries to establish recruitment relationships if they need graduates with potential and a reputation for great learning Fabrice Hénard dan Deborah Roseveare, "Fostering quality teaching in higher education: Policies and practices," An IMHE Guide for Higher Education Institutions, 2012, 7-11.. When students go to college, they not only broaden their knowledge in a particular area, but students also mature throughout time. Make many friends from different backgrounds. Students may use these friendships to organize study sessions, chat about task ideas, offer and assist one other when studying difficulties arise, and engage in other enjoyable activities. By

\footnotetext{
${ }^{6}$ Kimberly E. Arnold dan Matthew D. Pistilli, "Course signals at Purdue: Using learning analytics to increase student success," dalam Proceedings of the 2nd international conference on learning analytics and knowledge, 2012, 267-70.

${ }^{7}$ Christopher S. Wisniewski dan Melissa B. Hortman, "Comparison of pharmacy students randomized to receive drug information reference education via recording or interactive Moodle lesson," International Journal of Educational Technology in Higher Education 16, no. 1 (2019): 1-8.

8 Juan C. Burguillo, "Using game theory and competition-based learning to stimulate student motivation and performance," Computers \& education 55, no. 2 (2010): 566-75.

9 Seyed Mohammad Hassan Hosseini, "Competitive team-based learning versus group investigation with reference to the language proficiency of Iranian EFL intermediate students," International Journal of Instruction 7 , no. 1 (2014).

10 Fabrice Hénard dan Deborah Roseveare, "Fostering quality teaching in higher education: Policies and practices," An IMHE Guide for Higher Education Institutions, 2012, 7-11.
} 
establishing a company that fosters relationships, students will have access to many opportunities that will allow them to achieve a variety of goals.

Research shows that the role of student organizations is to help and train students to manage time well because, in the organization, each member has their duties and roles that must be completed and makes students appreciate every second that passes. ${ }^{11}$ Then students can choose a club or association that suits their hobbies and interests. Getting involved with an association will give students much engagement that they do not get in school. In addition to having various encounters Karen Seashore Louis, Beverly Dretzke, dan Kyla Wahlstrom, "How does leadership affect student achievement? Results from a national US survey," School effectiveness and school improvement 21, no. 3 (2010): 315-36., students will have the opportunity to learn how to work with groups, correspondence, manage freedom to build fruitful connections in future professions, and further develop authority's ability. In addition, with many associations, students can prepare for self-investigation such as competition, competition, or other assignments. They will undoubtedly be far more influential in maintaining the possibility of being on top in their future work. In essence, students will become more mature and play a role like professionals in work assignments. ${ }^{12}$

One way to become a great student is to have an open mind! It will be easier for students to talk about various topics if they have an open attitude. Try to take time to discuss students' ideas with friends, professors, or the intellectual community at school. ${ }^{13}$ Students will find new ideas, be allowed to explore the world and get input that may be critical of their lecturers. As we discuss this issue, remember that accepting other people's criticism can help students improve themselves better. ${ }^{14}$ Believe them when they say that by exchanging ideas and opinions with many people, students' knowledge will develop without trying hard. In essence, if students want to achieve success, they are asked to have the courage to be different and learn independently. Likewise, lecturers must be accustomed to accepting openmindedness and voice as a means to mature an independent learning climate.

Having a mentor may not be that important, but if students want to face a robust educational program, ongoing assignments, and lots of learning while pursuing higher education. When students feel stressed, they can seek help from a guide and motivational support. ${ }^{15}$ The best tutors, also known as experienced tutors, can guide students in the right direction. They will support students by helping them move forward and empowering students when faced with academic challenges and difficulties. The greatest coaches will want to give students advice and suggestions on coping with certain situations, focusing student

11 Karen Seashore Louis, Beverly Dretzke, dan Kyla Wahlstrom, "How does leadership affect student achievement? Results from a national US survey," School effectiveness and school improvement 21, no. 3 (2010): 315-36.

12 Brian A. Jacob dan Jonah E. Rockoff, Organizing schools to improve student achievement: Start times, grade configurations, and teacher assignments (Brookings Institution, Hamilton Project Washington, DC, 2011).

${ }^{13}$ Rebecca Covarrubias dkk., "You never become fully independent': Family roles and independence in firstgeneration college students," Journal of Adolescent Research 34, no. 4 (2019): 381-410.

${ }^{14}$ Rachael Field, James Duffy, dan Anna Huggins, "Independent learning skills, self-determination theory and psychological well-being: Strategies for supporting the first year university experience," dalam Proceedings of the 17th International First Year in Higher Education Conference (Queensland University of Technology, 2014), 1-10.

15 Zahava Moked dan Anat Drach-Zahavy, “Clinical supervision and nursing students' professional competence: support-seeking behaviour and the attachment styles of students and mentors," Journal of advanced nursing 72, no. 2 (2016): 316-27. 
energy, and concentrating. ${ }^{16}$ If they are unsure how to cope with their assignments and obligations, the guide can also help students change them. Good mentors might offer students a better perspective on which exercises are more attractive in a student's professional and personal life by breaking things down by importance. All coaches can do the same thing so that there is no student without a path to the academic success that campuses and students want. $^{17}$

\section{METHOD}

This study examines the relationship between the college's choice of majors and the success of learning for the future of work based on students' abilities. ${ }^{18}$ The researcher thinks that the significant selection of majors based on aptitude will determine a student's future performance. So, to verify this hypothesis, we looked at various types of relevant literature from various educational and higher education magazine publications. For example, ERIC, Google Book, Elsevier, Sagepub, Taylor, and France, all of which were published ten years ago, are among the publications of concern. ${ }^{19}$ We used phenomenological methods to construct this qualitative research. When students begin their study, we look at as much data as possible that addresses essential factors for student choice and academic achievement. We use data coding, assessment, and in-depth interpretation methodologies to answer questions about the validity principle. In reviewing the process of reporting the results of this study, we followed the experts of qualitative study data. ${ }^{20}$

\section{RESULTS AND DISCUSSION}

\section{University Merdeka to gain talent}

The concept of independent learning initiated by Nadiem Makarim has a worthy goal to be happy in their education. Students are given the freedom to access knowledge. ${ }^{21}$ The curriculum no longer limits the concept of independent learning, but students and teachers must be creative to reach knowledge. Independent learning has been given a package of strategies, including independent learning policies implemented through independent

\footnotetext{
${ }^{16}$ Julie López Figueroa dan Gloria M. Rodriguez, "Critical mentoring practices to support diverse students in higher education: Chicana/Latina faculty perspectives," New Directions for Higher Education 2015, no. 171 (2015): 23-32.

17 Ana Garcia-Melgar, Julianne East, dan Noel Meyers, "Peer assisted academic support: a comparison of mentors' and mentees' experiences of a drop-in programme," Journal of Further and Higher Education, 2021, 1-14.

18 Zahra Nelissa, Sri Astuti, dan Martunis Martunis, "Identifikasi Faktor yang Mempengaruhi Siswa dalam Proses Pemilihan Jurusan Pendidikan Lanjutan (Studi pada Siswa Kelas XI SMA Negeri 5 Banda Aceh)," JPPI (Jurnal Penelitian Pendidikan Indonesia) 4, no. 1 (2018): 78-83.

19 Nittaya Campbell, "Promoting intercultural contact on campus: A project to connect and engage international and host students," Journal of studies in international education 16, no. 3 (2012): 205-27.

20 Karen J. Nelson dkk., "Good practice for enhancing the engagement and success of commencing students," Higher Education 63, no. 1 (2012): 83-96.

${ }^{21}$ Nurhayani Siregar, Rafidatun Sahirah, dan Arsikal Amsal Harahap, "Konsep Kampus Merdeka Belajar di Era Revolusi Industri 4.0," Fitrab: Journal of Islamic Education 1, no. 1 (2020): 141-57. Purniadi Putra dan Aslan, "PENGEMBANGAN BAHAN AJAR BERBASIS IMTAQ DAN IPTEK DI ERA REVOLUSI INDUSTRI 4.0 PADA MATA PELAJARAN SAINS MADRASAH IBTIDAIYAH," Ta Limuna: Jurnal Pendidikan Islam 9, no. 1 (30 Maret 2020): 1-15, https://doi.org/10.32478/talimuna.v9i1.345. Purniadi Putra dkk., "The Relevancy on Education Release Revolution 4.0 in Islamic Basic Education Perspective in Indonesia (An Analysis Study of Paulo Freire's Thought)," Test Engineering \& Management 83 (2020): 10256-63.
} 
campuses. ${ }^{22}$ An independent campus policy allows students to read for three semesters outside of the investigative program.

This privilege is a token of gratitude and allows for sharing knowledge and development across study programs at each institution and between universities. Job training, entrepreneurship, research, village projects, humanitarian projects, student exchanges, and other pick-ups are included in Permendikbud number 3 of 2020 concerning National Higher Education Standards. ${ }^{23}$ This movement provides an opportunity to promote innovation and development to turn this training load into permanent course credits. The independent learning program aims to liberate teachers and students. As the spirit of the Father of National Education, Ki Hadjar Dewantara is to liberate humans, in this case, education. ${ }^{24}$

According to H. Masduki Duryat, ${ }^{25}$ independent learning also implies that schools, students, and teachers can be creative, study freely, and produce creative and innovative students. He thinks that schools and teachers will be committed to being creative in the classroom and reflecting on progress and how it impacts the future growth of their children. ${ }^{26}$ To support this, the government has a Merdeka Campus which is a comprehensive career preparation program organized by the Ministry of Education, Culture, Research, and Technology to educate the best generation of Indonesia ${ }^{27}$ through his work on the relevance of Ki Hajar Dewantara's thoughts to the concept of Merdeka Learning Nadhim Makarim. Thus, the Merdeka Campus is part of the Merdeka Learning policy, allowing students to acquire skills according to their talents and interests by going directly into the world of work as preparation for future careers. ${ }^{28}$

The choice of majors according to talent usually students will learn for real with a bit of effort but the results will be a lot. Because talent is like a saying, be what students are, it might be easy to happen. ${ }^{29}$ Generally, graduates who have innate talent abilities will easily carve out high achievements to be very relevant to the requirements in the world of work because organizations or businesses need abilities accompanied by someone's natural talent that can support the achievement of benefits and mark their organization towards more

22 Mohammad Tohir, "Merdeka Belajar: Kampus Merdeka," 2020. Aslan Aslan, HIDDEN CURRICULUM (Pena Indis, 2019). Aslan dan Wahyudin, Kurikulum dalam Tantangan Perubahan (Medan: Bookies Indonesia, 2020), https:/ / scholar.google.com/scholar?oi=bibs\&hl=en\&cluster=17745790780728460138.

23 Siti Khodijah, "Penerapan Media Playdough Dalam Meningkatkan Kreatifitas Anak Usia Dini Di Kelompok Bermain Mutiara Bunda Desa Wedarijaksa Pati Tahun Pelajaran 2019/2020” (PhD Thesis, IAIN KUDUS, 2020).

${ }^{24}$ Heri Maria Zulfiati, "Pendidikan Karakter Perspektif Ki Hadjar Dewantara Dalam Membentuk Generasi Unggul Era Revolusi Industri 4.0,” dalam Prosiding Seminar Nasional PGSD UST, vol. 1, 2019.

${ }^{25}$ H. Masduki Duryat, Paradigma Pendidikan Islam: Upaya Penguatan Pendidikan Agama Islam di Institusi yang Bermutu dan Berdaya Saing (Penerbit Alfabeta, 2021).

${ }^{26}$ Wahyu Djoko Sulistyo, "Learning Activities from Learning Resources: Pemanfaatan dan Pemaknaan Situs Sejarah Kawasan Alun-Alun Merdeka Kota Malang Pemanfaatan dan Pemaknaan Situs Sejarah Kawasan AlunAlun Merdeka Kota Malang," Jurnal Pendidikan Sejarah Indonesia 2, no. 1 (2019): 49-63.

27 Eka Prasetya Berkamsyah, "Relevansi pemikiran Ki Hajar Dewantara dengan Konsep Merdeka Belajar Nadhim Makarim" (PhD Thesis, UIN Sunan Ampel Surabaya, 2021).

${ }^{28}$ Fajarika Ramadania dan Dana Aswadi, "Blended learning dalam merdeka belajar teks eksposisi," Stilistika: Jurnal Bahasa, Sastra, dan Pengajarannya 5, no. 1 (2020): 10-21.

29 Dela Khoirul Ainia, "Merdeka Belajar Dalam Pandangan Ki Hadjar Dewantara Dan Relevansinya Bagi Pengembanagan Pendidikan Karakter," Jurnal Filsafat Indonesia 3, no. 3 (2020): 95-101. 
progress. These achievements become student profiles that clients can view. Familiarity with achievement must be done from the start. ${ }^{30}$

When students have attention, positive people are also formed, legitimate character, about the achievements of others, embracing truth, and the soul of common sense is turbulent. Domineering students must be held in high esteem and rewarded to emerge on a professional pathway setting commensurate with their achievements because talent and achievement are two aspects that cannot be separated in a person's career training and education system. In a simple understanding that talent is a person's fundamental ability to learn relatively quickly compared to other people, the results are even better with selfachievement, which is the result of one's efforts. ${ }^{31}$

\section{Talent and achievements at the international level}

Talent and achievement are two variables that support each other, with the number of students throughout Indonesia reaching more than 8 million. Meanwhile, the number of universities is more than 4,000 . This fact becomes the capital for Indonesia to make a sincere commitment to developing student achievement further to succeed at the international level. ${ }^{32}$ In today's digital era, nothing is impossible where student achievement is created through various exercises, including contests, studios, and capacity building indicated by their latent capacity. Online learning solutions will emerge for the nation's children with international achievements. There are several procedures for achieving student achievement at a global level, including developing new enhancements and possibilities for achievement, building great mentality and personality, setting up unique student biological systems (networks and achievement programs), participating in world competitions regularly.

Moreover, work with improvement. ${ }^{33}$ For example, in mechanical technology, groups from Indonesia have consistently won gold medals at global events, in science, mathematics, almost all winners at the general level become champions at the world level, and so on. What is meant by talent (aptitude)? In short, the notion of talent is an ability possessed by a person where the ability is inherent in him and can be used to do certain things faster and better than ordinary people. ${ }^{34}$ Another opinion says talent is an ability in a person from birth where this ability can be used to learn something quickly and with good results. Everyone has different talents and very diverse forms, such as musical talent, dancing, painting. Several factors also influence talent because talent can develop sooner or later. ${ }^{35}$

30 Abd Qodir, "Teori Belajar Humanistik Dalam Meningkatkan Prestasi Belajar Siswa," Pedagogik: Jurnal Pendidikan 4, no. 2 (2017).

31 Salwa Afniola, Ruslan Ruslan, dan Wiwit Artika, "INTEIEGENSI DAN BAKAT PADA PRESTASI SISWA,” Al-Din: Jurnal Dakwah dan Sosial Keagamaan 6, no. 1 (2020).

32 Iin Nurkarima, Novianti Puspitasari, dan Masna Wati, "Sistem Monitoring Penelusuran Minat Dan Bakat Mahasiswa," EXPLORE 10, no. 2 (2020).

${ }^{33}$ Kabag AAKPSI, "Prestasi Mahasiswa Politeknik Negeri Pontianak Bidang Minat \& Bakat," 2016.

34 SAMSUL ARIFIN, Umil Muhsinin, dan Devie Novallyan, "HUBUNGAN KEGIATAN EKSTRAKURIKULER TERHADAP INDEKS PRESTASI MAHASISWA MA'HAD AL-JAMI'AH” (PhD Thesis, UIN SULTHAN THAHA SAIFUDDIN JAMBI, 2019).

35 Yeh-cheng Chen dkk., "Using case-based reasoning method to design a return merchandise authorization system for supply chain management in Internet of Thing," dalam 2017 IEEE 17th International Conference on Communication Technology (ICCT) (IEEE, 2017), 1462-66. 


\section{Talent and achievement}

For students to be successful with brilliant achievements, the factors of attention, creative thinking, creativity, reflexivity, small voice, and autonomous self-will are God's gifts to humans that must be nurtured continuously so that learning achievement can be realized. ${ }^{36}$ Those governed have the primary responsibility to use their four ordinary skills, abilities, or gifts to the fullest, preferably to improve the social environment. The term ability refers to a person's abilities, traits, and attitudes from birth, such as someone very good at painting when he was only five years old or a child who had developed into a chess master at a very early age. ${ }^{37}$ Even though they were never trained or groomed, the ability was present from birth. When we think of talent, humans usually think of some extraordinary achievement in art, sport, or another field, as if it were a secret gift that only a few people possess. ${ }^{38}$

Of course, everyone would be easy to say, especially when only talking about the achievements achieved in a short time without taking into account the hundreds of hours of work required to achieve this extraordinary feat. When talent is broken down into component skills, which are pretty general and attainable, they can be trained and practiced. Teachers argue that although talent allows one to develop skills more quickly, one still has to put in the necessary time and work. ${ }^{39}$

Developing the talents of these student participants is a challenge for universities. ${ }^{40}$ However, every teacher must recognize the stages and ways of developing students' interests and talents, for example, by providing a stimulus. Give stimulation to students to explore more about themselves and the environment in their field of study. By observing the behavior of teachers, it will be possible to find out which direction to take. ${ }^{41}$ Pay attention to the intelligence and interest of students will also provide space for student self-exploration. Provide positive support. A student who is talented in a field will usually want to do or talk about it. Different types of talents, specific general abilities, and unusual abilities are two distinct types of abilities. General ability is defined as an essential, universal potential, meaning that it is owned by everyone. ${ }^{42}$ At the same time, extraordinary talents are skills that have extraordinary potential, which shows that not everyone has, for example, creative, administrative, teaching, athletic, and other unique talents, to be precise.

${ }^{36}$ Ulrich Teichler, "Research on the relationships between higher education and the world of work: Past achievements, problems and new challenges," Higher Education 38, no. 2 (1999): 169-90.

37 Eunjin Bang dan Dale R. Baker, "Gender differences in Korean high school students' science achievements and attitudes towards science in three different school settings.," Online Submission 3, no. 2 (2013): $27-42$.

${ }^{38} \mathrm{Li}$ Yuan dan Zhu Tiejun, "Empirical Research on the Creative Design Talents Cultivation of Sino-Foreign Cooperative Education Project in Local Engineering Universities," dalam International Conference on E-Learning, EEducation, and Online Training (Springer, 2020), 3-15.

39 D. Betsy McCoach dkk., "Developing talents: A longitudinal examination of intellectual ability and academic achievement," High Ability Studies 28, no. 1 (2017): 7-28.

${ }^{40}$ Karin Scager dkk., "How to persuade honors students to go the extra mile: Creating a challenging learning environment," High Ability Studies 24, no. 2 (2013): 115-34.

41 Michelle Trudgett, Susan Page, dan Stacey Kim Coates, "Talent war: recruiting Indigenous senior executives in Australian Universities," Journal of Higher Education Policy and Management 43, no. 1 (2021): 110-24.

42 Inger Beate Pettersen dkk., "From making gadgets to making talents: exploring a university makerspace," Education + Training, 2019. 
The verbal ability to convey thoughts through words - the mathematical capacity to represent concepts as numbers. ${ }^{43}$ Academic ability in combining words and numbers, thinking, organizing, reasoning in causal cases, formulating hypotheses, searching for valid normality or mathematical examples, and general level-headed view of life. That is what researchers, bookkeepers, and software developers know. More importantly, talent development is also a matter of how companies retain existing talent and not let it go or be taken by others. ${ }^{44}$

Academic ability significantly influences learning success ${ }^{45}$ as achievement refers to the results of what has been done or taught. The term achievement is used widely in many fields and is referred to as "ability." Because ability is a person's fundamental ability to learn quickly, which is the potential that individuals have from birth, this ability can produce extraordinary achievements when grown. In this way, some elements drive capacity building, such as internal factors and external components, both of which are very powerful in achieving extraordinary results. ${ }^{46}$

There are two kinds of talent factors: intrinsic factors and character factors in which the mental condition of a student's latent capacity development depends on himself and his emotions. This will help the idea of nurturing their inclinations and talents to be more optimistic and confident. The acquired components are the characteristics that help the individual's inability to progress as a distinguishing feature passed down from parents to children in all potentials through mysticism, which the individual claims from birth. ${ }^{4}$

When the women saw him, they were surprised by (his talent), so they cut off his hand and said: "Praise be to Allah, this is not human at all. This is, without a doubt, a noble and a holy messenger." This ability is closely related to the work of the big brain, as shown in the quote above. When the left and right hemispheres of the brain work together, the result is an acceptable, well-coordinated, intelligent outcome. Someone is an external influence. The family ward is the most minor or local area unit, similar to a small gathering in the public arena, and of course, the family is not just a substitute for relatives. However, it also gives family members unique abilities. ${ }^{48}$

Furthermore, people remain constant as individuals even when they are together in large groups. To become a talented person, an individual must go through a cycle. As a result, the capacity to achieve extraordinary results is undeniably influenced by the wider family environment and climate. The school environment is a place to find out how to influence learning achievement because if skills are developed in a school climate, it will have a positive effect on achieving outstanding results. ${ }^{49}$

${ }^{43}$ W. Newton Suter, Introduction to educational research: A critical thinking approach (SAGE publications, 2011).

44 Alexandra Lascu dkk., "Talent development in women's cricket: Perceptions and practices of elite players and coaches," International Journal of Sports Science \& Coaching, 2021, 17479541211012944.

45 Todd Stinebrickner dan Ralph Stinebrickner, "Learning about academic ability and the college dropout decision," Journal of Labor Economics 30, no. 4 (2012): 707-48.

46 Nimisha Patel dan Sharon Stevens, "Parent-Teacher-Student Discrepancies in Academic Ability Beliefs: Influences on Parent Involvement.,” School Community Journal 20, no. 2 (2010): 115-36.

${ }^{47}$ D. O. Fakeye, "Students' personal variables as correlates of academic achievement in English as a second language in Nigeria," Journal of social sciences 22, no. 3 (2010): 205-11.

48 Stinebrickner dan Stinebrickner, "Learning about academic ability and the college dropout decision."

${ }^{49}$ Saiying Steenbergen-Hu, Matthew C. Makel, dan Paula Olszewski-Kubilius, "What one hundred years of research says about the effects of ability grouping and acceleration on K-12 students' academic achievement: Findings of two second-order meta-analyses," Review of Educational Research 86, no. 4 (2016): 849-99. 


\section{CONCLUSION}

This section summarizes the results of a study that focuses on discussing the relationship between majors' choice and talent in achieving success in college. We believe that the presentation of our findings has answered this research problem validly. Our findings, for example, how the choice of majors that we examine from government regulations through independent campuses will have results in students and their future. The result is how the ability or talent will develop when the major they choose is compatible with their interests and desires. Because talent and achievement are two things that are closely related, students will be helpless and enthusiastic when they are faced with a lecture that they do not like. Other results, for example, if they are adequately nurtured and supported, Indonesian students can be in a row with other international students. Likewise, campus independence can develop talent and so students can take part and achieve high achievements.

\section{REFERENCES}

AAKPSI, Kabag. "Prestasi Mahasiswa Politeknik Negeri Pontianak Bidang Minat \& Bakat," 2016.

Afniola, Salwa, Ruslan Ruslan, dan Wiwit Artika. "INTeEEGENSI DAN BAKAT PADA PRESTASI SISWA." Al-Din: Jurnal Dakwah dan Sosial Keagamaan 6, no. 1 (2020).

Ainia, Dela Khoirul. "Merdeka Belajar Dalam Pandangan Ki Hadjar Dewantara Dan Relevansinya Bagi Pengembanagan Pendidikan Karakter." Jurnal Filsafat Indonesia 3, no. 3 (2020): 95-101.

Akhtar, Zarina. "A Comparative Study of Students Learning Style, Socio-economic Status and Learning Achievement of Developed and Under-developed Districts of Pakistan." Language in India 11, no. 6 (2011).

ALRowais, Azizah Saad. "The impact of flipped learning on achievement and attitudes in higher education." International Journal for Cross-Disciplinary Subjects in Education 4, no. 1 (2014): 1914-21.

Apriansyah, Sidik. "Hubungan antara prestasi belajar dengan perencanaan karir." PSIKOPED AGOGLA Jurnal Bimbingan dan Konseling 3, no. 2 (2014): 78-85.

ARIFIN, SAMSUL, Umil Muhsinin, dan Devie Novallyan. "HUBUNGAN KEGIATAN EKSTRAKURIKULER TERHADAP INDEKS PRESTASI MAHASISWA MA'HAD AL-JAMI'AH." PhD Thesis, UIN SULTHAN THAHA SAIFUDDIN JAMBI, 2019.

Arnold, Kimberly E., dan Matthew D. Pistilli. "Course signals at Purdue: Using learning analytics to increase student success." Dalam Proceedings of the 2 nd international conference on learning analytics and knowledge, 267-70, 2012.

Aslan, Aslan. HIDDEN CURRICULUM. Pena Indis, 2019.

Aslan dan Wahyudin. Kurikulum dalam Tantangan Perubahan. Medan: Bookies Indonesia, 2020. https://scholar.google.com/scholar?oi=bibs\&hl=en\&cluster $=1774579078072846013$ 8.

Bang, Eunjin, dan Dale R. Baker. "Gender differences in Korean high school students' science achievements and attitudes towards science in three different school settings." Online Submission 3, no. 2 (2013): 27-42.

Berkamsyah, Eka Prasetya. "Relevansi pemikiran Ki Hajar Dewantara dengan Konsep Merdeka Belajar Nadhim Makarim.” PhD Thesis, UIN Sunan Ampel Surabaya, 2021. 
Burguillo, Juan C. "Using game theory and competition-based learning to stimulate student motivation and performance." Computers \& education 55, no. 2 (2010): 566-75.

Campbell, Nittaya. "Promoting intercultural contact on campus: A project to connect and engage international and host students." Journal of studies in international education 16, no. 3 (2012): 205-27.

Chen, Yeh-cheng, C. N. Chu, Hung Min Sun, Ruey-Shun Chen, Mengru Tu, dan S. C. Lin. "Using case-based reasoning method to design a return merchandise authorization system for supply chain management in Internet of Thing." Dalam 2017 IEEE 17th International Conference on Communication Technology (ICCT), 1462-66. IEEE, 2017.

Covarrubias, Rebecca, Ibette Valle, Giselle Laiduc, dan Margarita Azmitia. "You never become fully independent': Family roles and independence in first-generation college students." Journal of Adolescent Research 34, no. 4 (2019): 381-410.

Duryat, H. Masduki. Paradigma Pendidikan Islam: Upaya Penguatan Pendidikan Agama Islam di Institusi yang Bermutu dan Berdaya Saing. Penerbit Alfabeta, 2021.

Fakeye, D. O. "Students' personal variables as correlates of academic achievement in English as a second language in Nigeria." Journal of social sciences 22, no. 3 (2010): 205-11.

Field, Rachael, James Duffy, dan Anna Huggins. "Independent learning skills, selfdetermination theory and psychological well-being: Strategies for supporting the first year university experience." Dalam Proceedings of the 17th International First Year in Higher Education Conference, 1-10. Queensland University of Technology, 2014.

Figueroa, Julie López, dan Gloria M. Rodriguez. "Critical mentoring practices to support diverse students in higher education: Chicana/Latina faculty perspectives." New Directions for Higher Education 2015, no. 171 (2015): 23-32.

Garcia-Melgar, Ana, Julianne East, dan Noel Meyers. "Peer assisted academic support: a comparison of mentors' and mentees' experiences of a drop-in programme." Journal of Further and Higher Education, 2021, 1-14.

Hénard, Fabrice, dan Deborah Roseveare. "Fostering quality teaching in higher education: Policies and practices." An IMHE Guide for Higher Education Institutions, 2012, 7-11.

Hendriarto, Prasetyono, Agus Mursidi, Nawang Kalbuana, Nurul Aini, dan Aslan Aslan. "Understanding the Implications of Research Skills Development Framework for Indonesian Academic Outcomes Improvement." Jurnal Iqra': Kajian Ilmu Pendidikan 6, no. 2 (15 Juli 2021): 51-60. https://doi.org/10.25217/ji.v6i2.1405.

Hosseini, Seyed Mohammad Hassan. "Competitive team-based learning versus group investigation with reference to the language proficiency of Iranian EFL intermediate students." International Journal of Instruction 7, no. 1 (2014).

Jacob, Brian A., dan Jonah E. Rockoff. Organizing schools to improve student achievement: Start times, grade configurations, and teacher assignments. Brookings Institution, Hamilton Project Washington, DC, 2011.

Khodijah, Siti. "Penerapan Media Playdough Dalam Meningkatkan Kreatifitas Anak Usia Dini Di Kelompok Bermain Mutiara Bunda Desa Wedarijaksa Pati Tahun Pelajaran 2019/2020.” PhD Thesis, IAIN KUDUS, 2020.

Lascu, Alexandra, W. Spratford, D. B. Pyne, dan N. Etxebarria. "Talent development in women's cricket: Perceptions and practices of elite players and coaches." International Journal of Sports Science \& Coaching, 2021, 17479541211012944.

McCoach, D. Betsy, Huihui Yu, Allen W. Gottfried, dan Adele Eskeles Gottfried. "Developing talents: A longitudinal examination of intellectual ability and academic achievement." High Ability Studies 28, no. 1 (2017): 7-28. 
Moked, Zahava, dan Anat Drach-Zahavy. "Clinical supervision and nursing students' professional competence: support-seeking behaviour and the attachment styles of students and mentors." Journal of advanced nursing 72, no. 2 (2016): 316-27.

Nelissa, Zahra, Sri Astuti, dan Martunis Martunis. "Identifikasi Faktor yang Mempengaruhi Siswa dalam Proses Pemilihan Jurusan Pendidikan Lanjutan (Studi pada Siswa Kelas XI SMA Negeri 5 Banda Aceh)." JPPI (Jurnal Penelitian Pendidikan Indonesia) 4, no. 1 (2018): 78-83.

Nelson, Karen J., Carole Quinn, Andrew Marrington, dan John A. Clarke. "Good practice for enhancing the engagement and success of commencing students." Higher Education 63, no. 1 (2012): 83-96.

Nurkarima, Iin, Novianti Puspitasari, dan Masna Wati. "Sistem Monitoring Penelusuran Minat Dan Bakat Mahasiswa." EXPLORE 10, no. 2 (2020).

Patel, Nimisha, dan Sharon Stevens. "Parent-Teacher-Student Discrepancies in Academic Ability Beliefs: Influences on Parent Involvement." School Community Journal 20, no. 2 (2010): 115-36.

Pettersen, Inger Beate, Elin Kubberød, Fredrik Vangsal, dan Axel Zeiner. "From making gadgets to making talents: exploring a university makerspace." Education+ Training, 2019.

Pham, Quoc Trung, dan Thanh Phong Tran. "Impact factors on using of e-learning system and learning achievement of students at several universities in Vietnam." Dalam International Conference on Computational Science and Its Applications, 394-409. Springer, 2018.

Putra, Purniadi dan Aslan. "PENGEMBANGAN BAHAN AJAR BERBASIS IMTAQ DAN IPTEK DI ERA REVOLUSI INDUSTRI 4.0 PADA MATA PELAJARAN SAINS MADRASAH IBTIDAIYAH." Ta Limuna: Jurnal Pendidikan Islam 9, no. 1 (30 Maret 2020): 1-15. https://doi.org/10.32478/talimuna.v9i1.345.

Putra, Purniadi, Hilmi Mizani, Abdul Basir, Ahmad Muflihin, dan Aslan Aslan. "The Relevancy on Education Release Revolution 4.0 in Islamic Basic Education Perspective in Indonesia (An Analysis Study of Paulo Freire's Thought)." Test Engineering \& Management 83 (2020): 10256-63.

Qodir, Abd. "Teori Belajar Humanistik Dalam Meningkatkan Prestasi Belajar Siswa." Pedagogik: Jurnal Pendidikan 4, no. 2 (2017).

Ramadania, Fajarika, dan Dana Aswadi. "Blended learning dalam merdeka belajar teks eksposisi." Stilistika: Jurnal Bahasa, Sastra, dan Pengajarannya 5, no. 1 (2020): 10-21.

Sarikhani, Rahele, Mostafa Salari, dan Vahid Mansouri. "THE IMPACT OF E-LEARNING ON UNIVERSITY STUDENTS'ACADEMIC ACHIEVEMENT AND CREATIVITY." Journal of Technical Education and Training 8, no. 1 (2016).

Scager, Karin, Sanne F. Akkerman, Albert Pilot, dan Theo Wubbels. "How to persuade honors students to go the extra mile: Creating a challenging learning environment." High Ability Studies 24, no. 2 (2013): 115-34.

Seashore Louis, Karen, Beverly Dretzke, dan Kyla Wahlstrom. "How does leadership affect student achievement? Results from a national US survey." School effectiveness and school improvement 21, no. 3 (2010): 315-36.

Siregar, Nurhayani, Rafidatun Sahirah, dan Arsikal Amsal Harahap. "Konsep Kampus Merdeka Belajar di Era Revolusi Industri 4.0." Fitrah: Journal of Islamic Education 1, no. 1 (2020): 141-57.

Steenbergen-Hu, Saiying, Matthew C. Makel, dan Paula Olszewski-Kubilius. "What one hundred years of research says about the effects of ability grouping and acceleration 
on K-12 students' academic achievement: Findings of two second-order metaanalyses." Review of Educational Research 86, no. 4 (2016): 849-99.

Stinebrickner, Todd, dan Ralph Stinebrickner. "Learning about academic ability and the college dropout decision." Journal of Labor Economics 30, no. 4 (2012): 707-48.

Sulistyo, Wahyu Djoko. "Learning Activities from Learning Resources: Pemanfaatan dan Pemaknaan Situs Sejarah Kawasan Alun-Alun Merdeka Kota Malang Pemanfaatan dan Pemaknaan Situs Sejarah Kawasan Alun-Alun Merdeka Kota Malang." Jurnal Pendidikan Sejarah Indonesia 2, no. 1 (2019): 49-63.

Suroso, Amat, Prasetyono Hendriarto, Galuh Nashrulloh Kartika Mr, Petrus Jacob Pattiasina, dan Aslan Aslan. "Challenges and Opportunities towards an Islamic Cultured Generation: Socio-Cultural Analysis." Linguistics and Culture Review 5, no. 1 (28 Juni 2021): 180-94. https://doi.org/10.37028/lingcure.v5n1.1203.

Suter, W. Newton. Introduction to educational research: A critical thinking approach. SAGE publications, 2011.

Teichler, Ulrich. "Research on the relationships between higher education and the world of work: Past achievements, problems and new challenges." Higher Education 38, no. 2 (1999): 169-90.

Tohir, Mohammad. "Merdeka Belajar: Kampus Merdeka,” 2020.

Trudgett, Michelle, Susan Page, dan Stacey Kim Coates. "Talent war: recruiting Indigenous senior executives in Australian Universities." Journal of Higher Education Policy and Management 43, no. 1 (2021): 110-24.

Wisniewski, Christopher S., dan Melissa B. Hortman. "Comparison of pharmacy students randomized to receive drug information reference education via recording or interactive Moodle lesson." International Journal of Educational Technology in Higher Education 16, no. 1 (2019): 1-8.

Yuan, Li, dan Zhu Tiejun. "Empirical Research on the Creative Design Talents Cultivation of Sino-Foreign Cooperative Education Project in Local Engineering Universities." Dalam International Conference on E-Learning, E-Education, and Online Training, 3-15. Springer, 2020.

Zulfiati, Heri Maria. "Pendidikan Karakter Perspektif Ki Hadjar Dewantara Dalam Membentuk Generasi Unggul Era Revolusi Industri 4.0." Dalam Prosiding Seminar Nasional PGSD UST, Vol. 1, 2019. 